\title{
Feasibility of municipal solid waste (MSW) as energy sources for Saudi Arabia's future Reverse osmosis (RO) desalination plants
}

\author{
Phillips O. Agboola ${ }^{1}$, Jehad Saleh ${ }^{2}$ \\ ${ }^{1}$ King Saud University, Mechanical Engineering Department, College of Applied Engineering, (Al Muzahimiyah Branch), \\ Riyadh, Kingdom of Saudi Arabia \\ ${ }^{2}$ King Saud University, Chemical Engineering Department, College of Engineering, Riyadh, Kingdom of Saudi Arabia \\ "Corresponding author: e-mail: pagboola@ksu.edu.sa
}

\begin{abstract}
The Kingdom of Saudi Arabia (KSA) generates between 1.4-1.75 kg/person/day of Municipal Solid Waste (MSW) that accounts for over 16 million tons of MSW/year. The solid waste collected from different sources is dumped in landfills, thereby creating environmental concerns. In this paper, the potential of solid waste as an energy source (Waste to Energy (WTE)) for Reverse Osmosis (RO) water purification was evaluated. The KSA is known for its acute fresh water shortages and uses desalination technology in meeting its daily water requirements; a process that is energy intensive. The evaluation of the energy content of MSW shows a potential to produce about 927 MW in 2015, based on a total mass burn, and about 1,692 MW in 2032. The MSW-WTE plants can produce about $1.5 \%$ of the targeted $120 \mathrm{GW}$ of energy for 2032. For the R.O system, it will give approximately $16.8 \%$ of the daily fresh water needed for total mass burn and $2.4 \%$ with the recycling option.
\end{abstract}

Keywords: municipal solid waste, reverse Osmosis, energy content, waste to energy, water.

\section{INTRODUCTION}

MSW is an inevitable by-product of human activities, especially in urban communities with high income. Rapid rural-urban migration coupled with industrial growth has swiftly amplified the diversity and volume of Municipal waste. The KSA's vast crude oil reserve (wealth) is a primary driver of its rapid industrialization, high income earning and fast urbanization that has resulted in high air pollution and the municipal solid waste rate. With a population of about 30 million $^{1}$, the KSA generates more than 16 million tons of solid waste per year. The MSW, contingent upon the moisture and energy content of the waste materials, is a good fuel source that can replace coal or fossil fuel in some applications. Every ton of MSW, if processed in a WTE facility, can save a one-quarter $(1 / 4)$ ton of $\mathrm{coal}^{2,3}$. The thermal treatment of MSW results in the generation of 500-600 KWh of electricity per ton of MSW combusted ${ }^{2,3}$. This renewable energy source is untapped in the KSA, where population increase, high income, and urbanization are fueling the MSW generation at an exponential rate (Fig. 1). Figure 1 shows the trend of population, urban population and

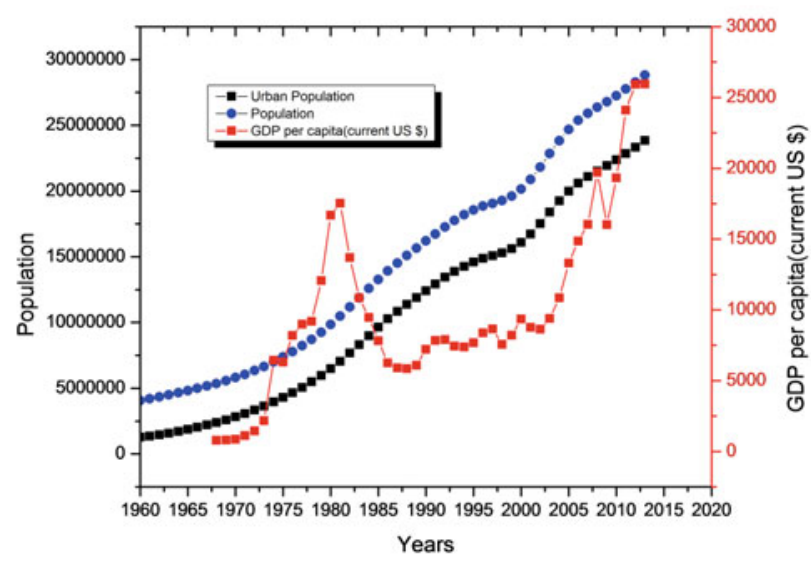

Figure 1. Total Population, Urban Population and GDP per capita of the $\mathrm{KSA}^{1,4}$ gross domestic product (GDP) per capita (current US\$) from 1960 to 2013 in the KSA. These parameters are believed to fuel cities' solid waste.

According to the US Energy Information Admini-

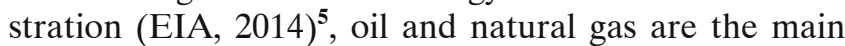
sources of energy in the KSA for transportation, electricity and water purification processes. The country consumed about 2.9 million barrels of oil per day (bbl/d) in 2013 . This amount was almost double the consumption in 2000, an average production of about 11.6 million bbl/ day, of which 9.6 million bbl/d was crude oil production and 2 million bbl/d was non-crude liquids ${ }^{5}$. The local daily consumption of $25 \%$ of the total production is high and needs to decrease significantly to increase the KSA's crude oil exportation share, especially with the low price of crude petroleum and the availability of renewable energy resources that can complement it. Furthermore, the instabilities in oil prices and environmental issues associated with greenhouse gas (e.g., carbon dioxide) emissions have forced researchers to focus on other renewable sources such as solar, wind and MSW $^{6}$. MSW is generated in homes, commercial outlets and other sources whose activities are similar to those of households and business offices. For example, waste from offices, hotels, supermarkets, shops, schools, institutions, and from municipal services such as street cleaning and maintenance of recreational areas ${ }^{6,7}$. The primary composition of waste is waste wood, plastics, papers and cartons, metals, glass, construction and demolition waste, green waste, tires, household solid waste and street cleaning waste. Riyadh, the capital of the KSA with a population of 6 million, has a long-term average population growth of about $2.95 \%$. The production rate of MSW in the KSA is about $1.4-1.75 \mathrm{~kg} /$ person/ day $^{\mathbf{8 , 9}, \mathbf{1 0}}$. According to Khan and Kaneesamkandi (2013), the solid waste generation rate per capita in the KSA increased from 1.4 in the year 2007 to 1.75 by the year $2012^{9}$. Increasing solid waste production in the KSA has increased the problem of waste disposal without affecting the environment and human health. In the KSA, most of the MSW is disposed directly into landfill, as 
against the practices in other countries such as the EU countries and China. Figure 2 shows the differences in waste treatments in the KSA, China and the EU. In the KSA, each municipal government is responsible for the collection of waste, whereby the MSW is collected from houses or communal bins by trucks and disposed of in landfills or dumpsites ${ }^{\mathbf{8}, 9}$. The EU countries utilize waste separation at source (homes and commercial sites), a crucial factor to its high percentages in recycling and composting. The source separation allows the sorting of the waste into major components, which greatly assists in improving recycling and composting options.
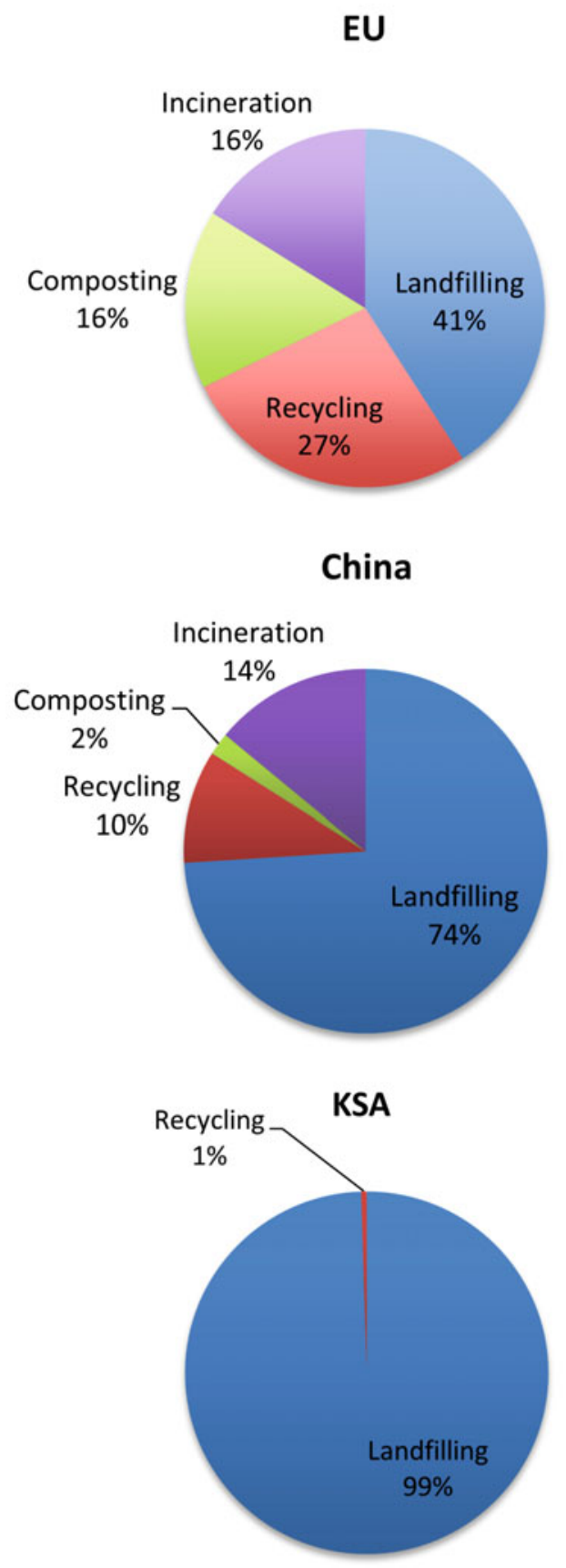

Figure 2. Differences in waste treatment in the EU, China and the $\mathrm{KSA}^{11,12,13}$

The pressure on water demand in the KSA is linked to increasing population growth rate and low recharge of the underground aquifers due to low yearly precipitation. The country is situated in the Arabian Peninsula, known for its arid climatic condition. According to Chowdhury and $\mathrm{Al}-\mathrm{Zahrani} \mathbf{1 4}^{\mathbf{1 4}}$, the non-renewable groundwater reserves are estimated to be between 259.1-760.6 BCM and the total internal renewable water estimated to be 2.4 $\mathrm{BCM} / \mathrm{year}$. The demand for domestic water increased astronomically from about $200 \mathrm{MCM}$ in 1970 to 2475 MCM in 2012. This increment is attributed to the wide-range of developments in the socioeconomic progress of the country fueled by the high price of oil before 2014 . Population, high income and the "welfare economy" practice in the KSA are responsible for the high rise in domestic water demand. Figure 3 shows the trend in the domestic water demand from 1970 to 2012.

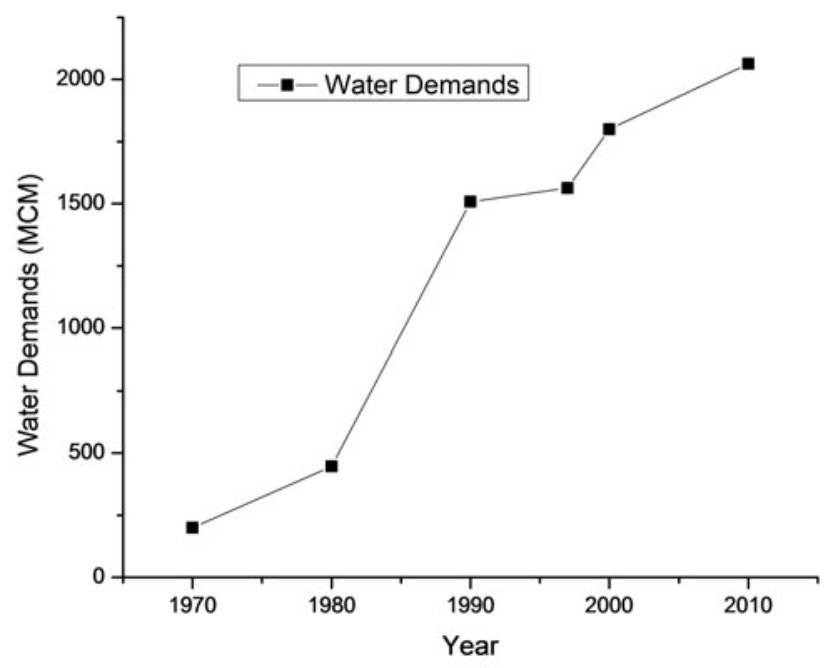

Figure 3. Growth of domestic water demands in the KSA in $\mathrm{MCM} /$ year $^{15}$

The domestic water requirements are met through two sources, namely, ground water aquifers and seawater desalination. Seawater desalination offsets more than $60 \%$ of the domestic water demand. According SWCC, desalination production increased from 200 million $\mathrm{m}^{3} /$ year in 1980 to 1495 million $\mathrm{m}^{3} /$ year in $2012^{\mathbf{1 6}}$. Using the Ouda $(2014)^{17}$ methodology, the water demand forecast was predicted using three scenarios. The first was the optimistic scenario using the government's plan for water sector development as seen in the KSA's Ninth Development Plant ${ }^{18}$. The plan assumes domestic, industrial and agricultural water demand grows at $2.1 \%$, $5.5 \%$ and $-3.7 \%$, respectively. This case is said to be optimistic because, in fact, the average growth rate for the past two decades has been $6 \%, 7.5 \%$ and $-1.05 \%$, respectively, for the domestic, industrial and agricultural water demand. The second will be the moving average of the optimistic and pessimistic scenarios. The third scenario is the pessimistic demand growth rate of the last two-decade's average growth rate of $6 \%, 7.5 \%$ and $-1.05 \%$ for domestic, industrial and agricultural water demand, respectively.

Table 1 shows the growth rate of the three scenarios for sectoral water demand in the KSA. The domestic and industrial water demand is supplied mainly from desalination and groundwater sources, while the agricultural water demand is mostly from groundwater sources. The fast depletion of non-renewable groundwater resources and the deterioration of the water quality are due to water withdrawal exceeding natural replenishment. The decrease in the demand for agricultural water was due 
Table 1. Demand growth rate scenarios ${ }^{18}$

\begin{tabular}{|l|c|c|c|}
\hline Scenario & Domestic [\%] & Industrial [\%] & Agricultural [\%] \\
\hline Optimistic & 2.1 & 5.5 & -3.7 \\
\hline Moving Average & 4.05 & 6.5 & -2.375 \\
\hline Pessimistic & 6 & 7.5 & -1.05 \\
\hline
\end{tabular}

to government policies of minimizing farming activities in the KSA and importing most of its agricultural products from abroad to lessen the use of non-renewable groundwater resources (fossil water), thereby preventing seawater encroachment and high salinity in the aquifers. Furthermore, the growth of industries in the KSA can be seen in the increasing industrial water demand over the years. Table 2 shows the increasing contribution of desalinated water in meeting the domestic water need of the KSA, which invariably increases its domestic crude oil consumption.

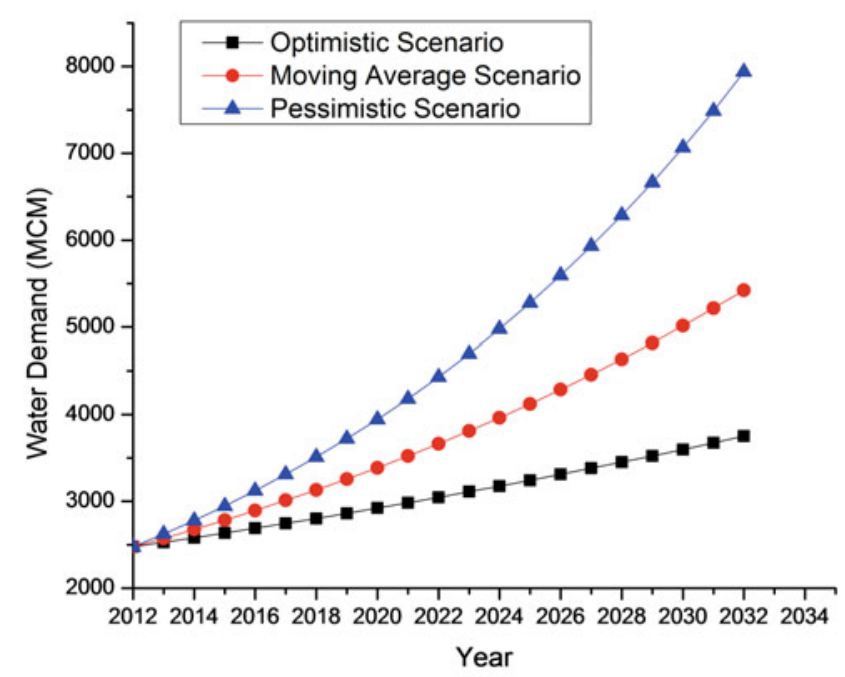

Figure 4. Projected domestic water demand based on three scenarios using data from ${ }^{19}$

Water demand forecast based on the three scenarios shows increments, with the optimistic showing a linear trend while the moving average and pessimistic show an exponential increase from 2012 to 2032 . In the year 2032, the KSA's water demand may rise by $52 \%$ in the optimistic scenario. The moving average and pessimistic scenarios forecasted increments ranging from $119 \%-221 \%$ of the 2012 demand (see Fig. 4). The increasing demand for domestic water means that desalination facilities need to be expanded to meet future demand. The KSA uses approximately 1.5 million barrels of crude oil equivalent per day for desalination and electricity generation ${ }^{\mathbf{2 0}}$.
Figure 5 shows the KSA's crude oil production and domestic crude oil consumptions. The government is putting strategies and robust policies in place to reduce its heavy reliance on crude oil for future desalination and electricity plants. These government policies have seen the establishment KACARE, a government agency responsible for renewable energy research, policies and deployment. KACARE is targeting about 54GW from renewable energy sources like solar PV, solar CSP and municipal solid waste, for desalination and electricity generation $^{21}$ (see Table 3 ). One practical and easy way to achieve this target is to utilize the abundance of MSW. MSW is a renewable energy and it is abundantly available on a daily basis in the landfills. The use of municipal solid waste for direct desalination or electricity generation for desalination will increase the efficiency of waste collection and management, which will, in turn, save the cities from waste pollution. The technology to process MSW has been established for years; it started with the use of incinerators, which solely burn the waste into gases and leave ash as a deposit. As interest in alternative energy has grown, advanced technology has progressed from the simple incinerators to WTE plants using non-recyclable, or a combination with recyclable, MSW as the fuel source. The heat from the combustion is used to turn water into steam in a boiler. The generated steam can directly be used to heat homes or combine with a steam turbine for producing electricity ${ }^{22,23}$. However, the incineration process is perceived to be unfriendly to the environment due to the $\mathrm{CO}_{2}$ emissions ${ }^{24,25}$. Reducing the $\mathrm{CO}_{2}$ emissions has led to the development of new facilities for MSW processes integrated with $\mathrm{CO}_{2}$ capturing mechanisms. The new technologies for MSW processes are pyrolysis, conventional gasification and plasma arc gasification with potentials for $\mathrm{CO}_{2}$ netting accessories.

There is only one MSW landfill located in the southeast area and this is almost $25 \mathrm{~km}$ away from Riyadh city. The overall total area is around 8 million $\mathrm{m}^{2}$. This station daily receives in the range of two thousand vehicles transporting several thousand tons per day of various types of MSW. Table 4 shows the component of the solid waste and Table 5 depicts the energy content of different types of waste. The daily waste is sorted with

Table 2. Water supply in the KSA through desalination and wells ${ }^{19}$

\begin{tabular}{|l|c|c|c|c|c|}
\hline Period & $\begin{array}{c}\text { Desalinized Water } \\
(\mathrm{DW})\left[\mathrm{m}^{3}\right]\end{array}$ & DW [\%] & Wells Water (WW) $\left[\mathrm{m}^{3}\right]$ & WW [\%] & Total Supply [m $\left.{ }^{3}\right]$ \\
\hline $2005-2006$ & $395,061,256$ & 33 & $804,858,695$ & 67 & $1,199,919,951$ \\
\hline $2006-2007$ & $1,036,988,746$ & 55 & $838,266,625$ & 45 & $1,875,255,371$ \\
\hline $2007-2008$ & $1,065,416,361$ & 54 & $909,100,024$ & 46 & $1,974,516,385$ \\
\hline $2008-2009$ & $1,070,068,541$ & 53 & $940,043,207$ & 47 & $2,010,111,748$ \\
\hline $2009-2010$ & $1,029,015,372$ & 51 & $981,055,536$ & 49 & $2,010,070,908$ \\
\hline $2010-2011$ & $1,330,741,178$ & 57 & $1,007,774,136$ & 43 & $2,338,515,314$ \\
\hline $2011-2012$ & $1,495,238,880$ & 60 & $979,740,464$ & 40 & $2,474,979,344$ \\
\hline
\end{tabular}

Table 3. Target Renewable Capacity by $2032^{21}$

\begin{tabular}{|l|c|c|c|c|c|}
\hline RE Type & Solar PV & Solar CSP & Wind & Waste-to-Energy & Geothermal \\
\hline Target Capacity & $16 \mathrm{GW}$ & $25 \mathrm{GW}$ & $9 \mathrm{GW}$ & $3 \mathrm{GW}$ & $1 \mathrm{GW}$ \\
\hline
\end{tabular}


Table 4. Components of solid waste ${ }^{27}$

\begin{tabular}{|l|l|}
\hline Category & \\
\hline General classification & Examples of waste \\
\hline Waste wood and its derivatives & Furniture, bulky, non-hazardous waste made from wood \\
\hline Plastics & Plastic bags, plastic bottles, plastic beads, no hazardous materials or liquids \\
\hline Metals & All types of paper and cardboard without other compounds attached \\
\hline Glass & Ferrous and non-ferrous \\
\hline Construction and demolition waste & Construction and demolition waste without hazardous waste \\
\hline Green waste & Remnants of trees and plants with a minimum amount of soil \\
\hline Tires & Tires \\
\hline Solid household wastes & Waste collected from the street \\
\hline Street cleaning waste & Waste from vacuuming and cleaning the streets \\
\hline
\end{tabular}

an operational capacity of 300 tons/day, which gives a $1.87 \%$ of total received waste free of hazardous and prohibited substances. The recycling activities in the landfill facility are mostly manual and labor intensive.

The aim of this work is to assess the contribution of MSW (as input to the WTE plants) from Riyadh landfill to water supply through desalination.

\section{METHODOLOGY}

The potential of the MSW will be evaluated for electricity production (for use in RO application). Two scenarios will be considered for the MSW, namely, Mass Burn, Mass-Burn with recycling, and direct conversion of tons of MSW to oil equivalent. The mass burn scenario entails the use of all the daily MSW as collected from the field for WTE purposes. Mass burn with a recycling scenario allows the removal of all recyclable constituents of the MSW before using the rest as input for the WTE. The two scenarios will be used to forecast the total electricity or thermal energy potential of MSW of Riyadh landfill up to the year 2032. The year 2014 was chosen as the base year for the estimate, and the MSW production rate used for Riyadh is $1.4 \mathrm{~kg} / \mathrm{capita}_{\mathrm{day}}{ }^{\mathbf{8}, 28,29}$. The caloric energy contents of the MSW, listed in Table $5^{28-31}$, were used for the energy contents of Riyadh landfill MSW for scenario's I and II. The combustion efficiencies of these incinerators are up to $30 \%$. For the purpose of this work, a combustion efficiency of $25 \%$ will be used, as recommended by Ouda et al. $(2013)^{28}$.

\section{RESULTS AND DISCUSSION}

The water demand forecast (Fig. 4) shows that the current water processing facilities will soon be inadequate in meeting the water needs of the KSA. In the year 2032, the KSA's water demand will increase by $52 \%$ using the optimistic scenario, while the moving average and pessimistic scenarios forecast increments of $119 \%$ and $221 \%$, respectively. The growing demand for water means that desalination facilities need to be expanded to meet future demand. These new desalination plants can utilize the MSW as an energy source for the process of water purification. MSF and MED are the main desalination technologies employed in the KSA for seawater purification due to the high salinity of the seawater. The recent technological advances in RO, especially its low energy consumption, improved membrane and efficient ways of handling bio-fouling, are opening up competition in the desalination market. The KSA is now making a massive investment in RO systems to replace its aging MSF/MED plants. This is evident in the recent

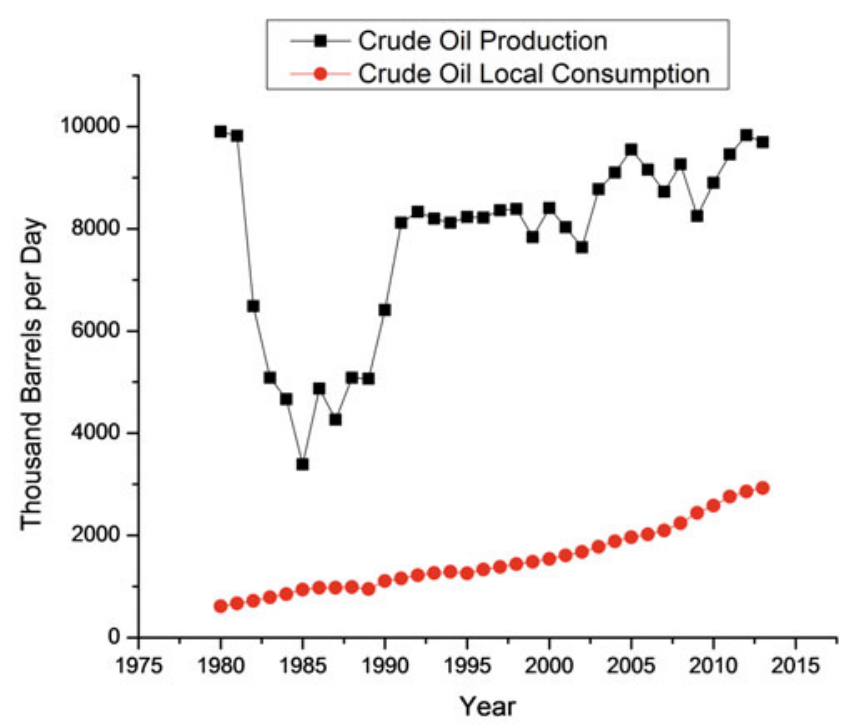

Figure 5. KSA Crude Oil production and Local Consumption ${ }^{26}$

construction of the largest solar-powered RO system, located in Al Khafji, KSA.

The energy requirement for these RO plants can be generated from the MSW, which is abundant and renewable. The production of MSW depends on population, and the population of the KSA is expected to grow at $2.95 \%$ per year, as projected by the Saudi Central Department of Statistics and Information ${ }^{1}$.

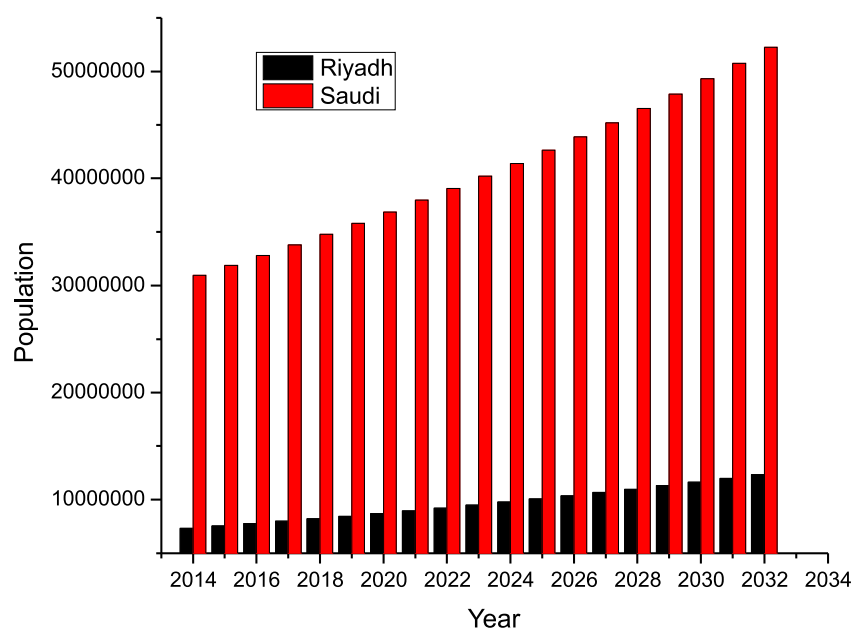

Figure 6. The forecasted population for Riyadh and the KSA

The projected population of the KSA and the capital (Riyadh) up to the year 2032 is presented in Figure 6. The continuous population growth, as seen in Figure 6 , will ensure a constant increase in the daily MSW for energy generation. The forecast for the year 2032 shows almost $70 \%$ increase in population from 2014, which will translate to a rise in the MSW generated for the year. The 
daily generated MSW for the KSA and the capital city (Riyadh) is shown in Figure 7. The daily MSW generated in 2014 was about $43,347,767 \mathrm{~kg}$, and this is predicted to reach about $73,154,500 \mathrm{~kg}$ by 2032 . This quantity of waste per day requires efficient management to avoid environmental disaster and health risk. This waste can be engaged for energy production, or can be sorted/separated into its components for identifying valuable products like paper, plastic and textiles for recycling. Figures 8 and 9 show the energy potential of the MSW from the whole country and Riyadh, the capital city. Each of the compositions of MSW has a particular heating value in its dry form, as shown in Table 6. By using the average heating values of each structure, the final calorific value of MSW was calculated. The energy potential for KSA and Riyadh MSW were estimated for two set-ups: Mass Burn and Mass Burn with recycling option.

The mass burn setup involves the total consumption of MSW collected, after moisture removal (dry weight), for

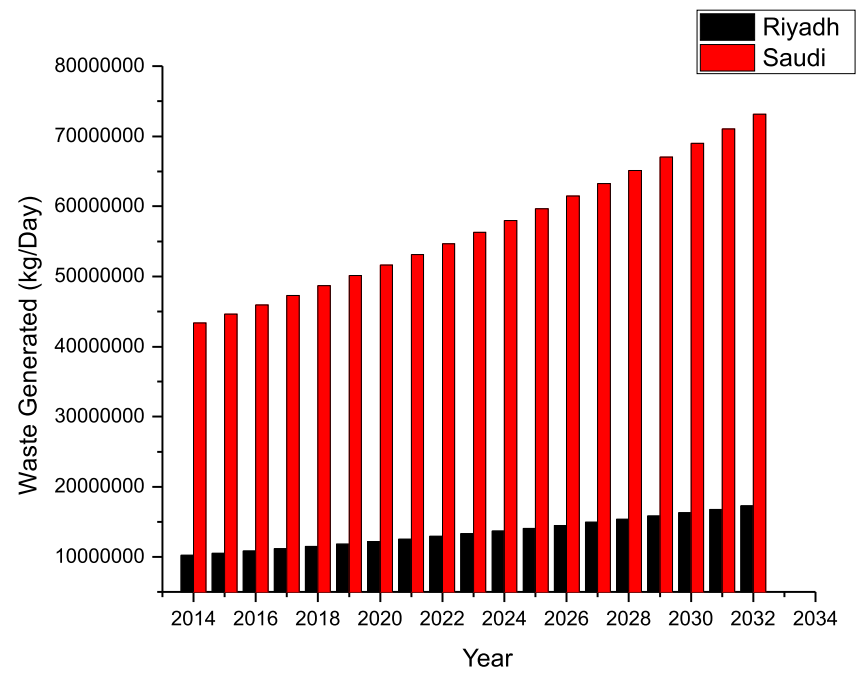

Figure 7. Daily waste generation in the KSA and Riyadh city Table 5. Energy content of different types of solid waste $\mathrm{e}^{\mathbf{2 8 - 3 1}}$ energy production. This means the MSW is not sorted for potential recycle of valued waste like paper, plastic, etc., and the energy content of the dry weight of the MSW is estimated at $10159.2 \mathrm{~kJ} / \mathrm{kg}$. On the other hand, the mass burn with recycling option setup involves the separation of the valuable products of paper, plastic, textiles and glass from the total MSW collected, the rest, after moisture removal, is used in energy production. The energy content for the mass burn with recycling setup is estimated at $3225.4 \mathrm{~kJ} / \mathrm{kg}$, which is far less when compared to the mass burn setup, because the materials removed from the MSW for recycling are high in energy content and economic value. The energy potentials (MW) for the KSA and Riyadh were estimated using population and the forecasted MSW. Figures 8 and 9 show the potential of the MSW-fueled WTE power plant in the KSA and Riyadh, the capital city, using the mass burn and mass burn with recycling option. In Figure 8, the total mass burn of all the MSW generated will have a capacity

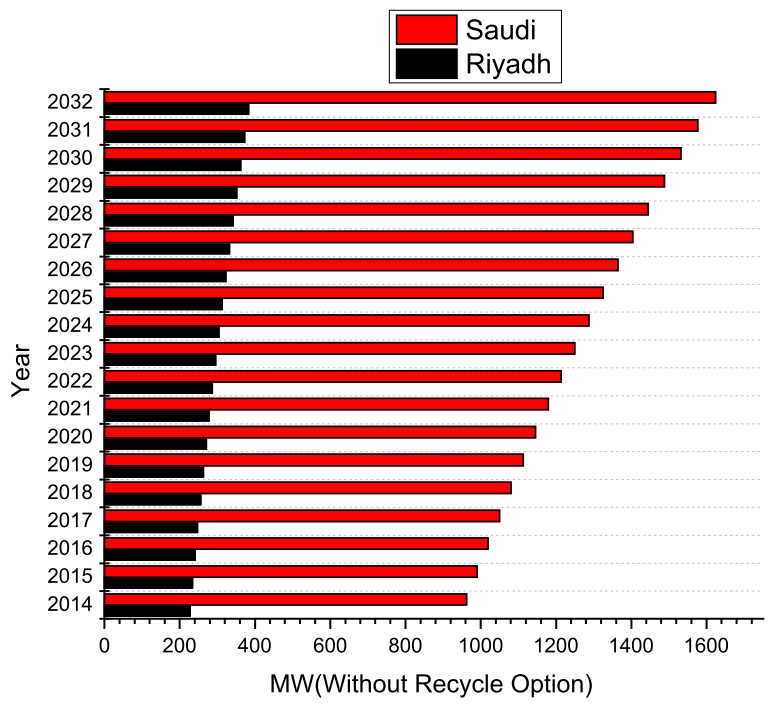

Figure 8. Mass Burn Energy Potential projection for Riyadh and the KSA

\begin{tabular}{|c|c|c|c|c|c|}
\hline Material & $\begin{array}{c}\text { Composition } \\
\text { [\% by wet mass] }\end{array}$ & $\begin{array}{c}\text { Moisture content } \\
{[\%]}\end{array}$ & $\begin{array}{c}\text { Dry waste } \\
{[\%]}\end{array}$ & $\begin{array}{c}\text { Energy content } \\
{[\mathrm{kJ} / \mathrm{kg}]}\end{array}$ & $\begin{array}{c}\text { Dry Weight Energy } \\
\text { Content }[\mathrm{kJ} / \mathrm{kg}]\end{array}$ \\
\hline Paper & 28.5 & 28.5 & 26.790 & 15816.8 & 4237.32072 \\
\hline Plastic & 5.2 & 2 & 5.096 & 32564.0 & 1659.46144 \\
\hline Glass & 4.6 & 2 & 4.508 & 0.0 & 0.00000 \\
\hline Wood & 8.0 & 19 & 6.480 & 16979.8 & 1100.29104 \\
\hline Textile & 6.4 & 14 & 5.504 & 18840.6 & 1036.986624 \\
\hline Organic & 37.0 & 52 & 17.760 & 5582.4 & 991.43424 \\
\hline Others & 10.3 & 9 & 9.373 & 12095.2 & 1133.683096 \\
\hline TOTAL & 100 & 100 & 75.511 & 101878.8 & 10159.17716 \\
\hline
\end{tabular}

Table 6. RO plants in the KSA with energy consumption per $\mathrm{m}^{3} 16$

\begin{tabular}{|c|c|c|c|c|c|c|}
\hline Sector & Location & Plant & $\begin{array}{l}\text { Installed } \\
\text { Capacity } \\
{\left[\mathrm{m}^{3} / \text { day }\right]}\end{array}$ & $\begin{array}{c}\text { Water Production } \\
\text { in } 2014 \\
{\left[\mathrm{~m}^{3}\right]}\end{array}$ & $\begin{array}{c}\text { Energy Consumption } \\
\text { in } 2014 \\
\text { [KWh] }\end{array}$ & $\begin{array}{c}\text { Power consumption to } \\
\text { produce } 1 \mathrm{~m}^{3} \text { of water in } \\
2014 \\
{\left[\mathrm{KWh} / \mathrm{m}^{3}\right]}\end{array}$ \\
\hline \multirow{9}{*}{ Governmental } & Al-Jubail & Jubail RO & 90,909 & $16,970,276$ & $167,478,000$ & 9.87 \\
\hline & $\begin{array}{l}\text { Ras Al } \\
\text { Khair }\end{array}$ & $\begin{array}{l}\text { Ras Al Khair } \\
\text { (RO) }\end{array}$ & 307,500 & $55,168,866$ & $162,332,000$ & 2.94 \\
\hline & & Jeddah RO1 & 56,800 & $21,425,576$ & $162,870,000$ & 7.60 \\
\hline & & Jeddah RO2 & 56,800 & $22,545,401$ & $166,143,000$ & 7.37 \\
\hline & Jeddah & Jeddah RO3 & 240,000 & $79,481,944$ & $402,986,000$ & 5.07 \\
\hline & Yanbu & Yanbu RO & 128,182 & $44,395,516$ & $312,390,000$ & 7.04 \\
\hline & $\mathrm{Haql}$ & Haql RO & 4,400 & $1,923,494$ & $19,310,000$ & 10.04 \\
\hline & Duba & Duba RO & 4,400 & $2,059,626$ & $20,493,000$ & 9.95 \\
\hline & Umlujj & Umlujj RO & 4,400 & 722,317 & $7,758,000$ & 10.74 \\
\hline \multirow[t]{2}{*}{ Private } & $\begin{array}{c}\text { Al- } \\
\text { Shuaiba }\end{array}$ & $\begin{array}{c}\text { Expansion } \\
\text { Shuaiba RO }\end{array}$ & 150,000 & $52,828,637$ & $240,346,000$ & 4.55 \\
\hline & Al-Shqaiq & Shqaiq RO & 212,000 & $70,039,594$ & 0 & 0.00 \\
\hline
\end{tabular}




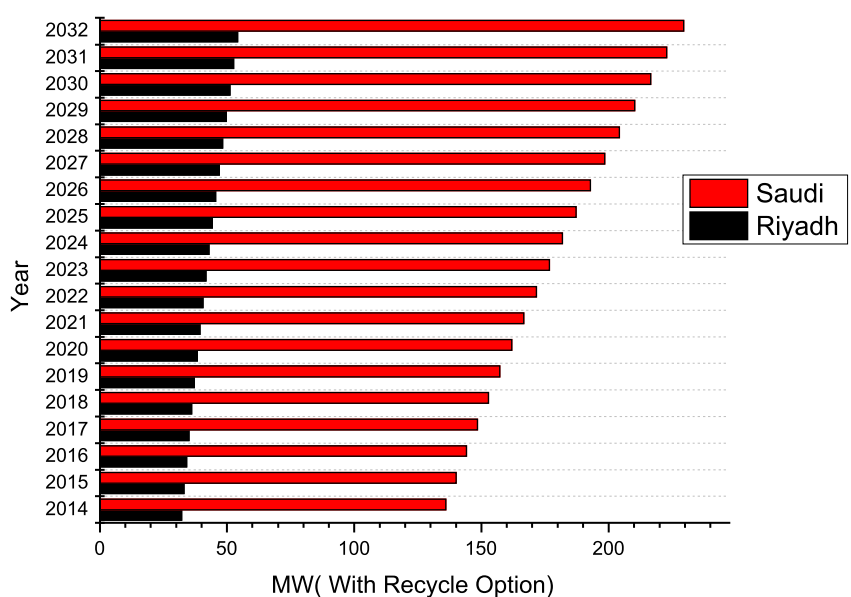

Figure 9. Mass Burn (with recycle option) Energy Potential projection for Riyadh and the KSA

of around $927 \mathrm{MW}$ in 2015 and around 1,692 MW in 2032. The MSW-WTE plants can produce about $1.5 \%$ of the targeted $120 \mathrm{GW}$ of energy for 2032. The recycling option to the MSW reduces the energy capacity of the MSW-WTE plants, $131 \mathrm{MW}$ for 2015 and $231 \mathrm{MW}$ for 2032 (see Fig. 9), but has socioeconomic benefits such as job creation, financial benefit derived from the sales of recycled products, reduction in raw materials consumption (especially raw materials for plastic and paper) and reduction in environmental-ecological imbalances. Figures 10 and 11 show the MSW recycling potential for the KSA and Riyadh. The main recycled components are paper, plastic, textiles and glass. Although glass does

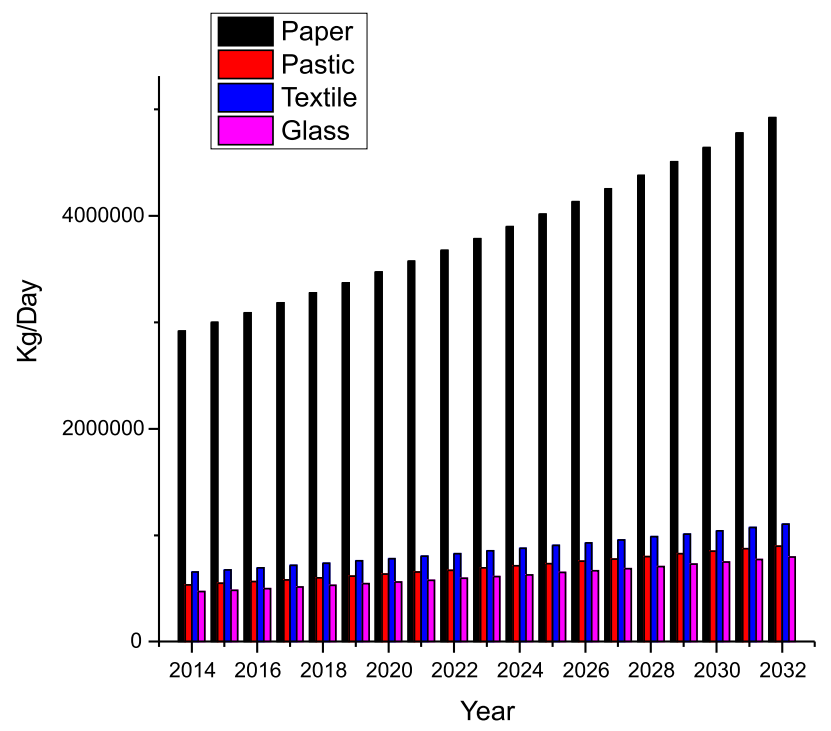

Figure 10. Riyadh's MSW Recycling Potentials

not have energy content, its economic value is obtained in recycling.

The KSA is poor in respect to fresh water availability within its geographical boundaries, its region, the Arabian Peninsula, being known for low precipitation and a desert climate. The scarcity of fresh water has led to the deployment of desalination technologies in augmenting its fresh water resources. Desalination accounts for more than $60 \%$ of water need in the KSA, as at 2011/2012. The growing need of fresh water due to increasing population and rise in socioeconomic activities is driving the desalination market in the $\mathrm{KSA}$, with the government always expanding its desalination facilities.
The SWCC, the government agency responsible for desalination in the country, produced 1.1 billion cubic meters of desalinated water in 2014, an increase of $10 \%$ from the previous year, from its 26 desalination plants through a network of 21 pipelines with a total length of $5,684 \mathrm{~km}$.

Seawater desalination is an expensive operation that requires a huge amount of energy, especially in the KSA where the MSF and MED are the engine horses of desalination. Moreover, these desalination plants only have an operational life in the range of 15-25 years. Thus, the KSA will need to replace this technology with desalination technology that requires far less energy relative to the MSF and MED. RO systems are seen to employ less energy in comparison with MSF, especially the new RO systems. Table 6 shows the energy requirement for $1 \mathrm{~m}^{3}$ of water using RO systems in the KSA with the best RO systems using $2.94 \mathrm{KWh} / \mathrm{m}^{3}$. The energy potential of MSW-WTE plants, as estimated for Riyadh and the $\mathrm{KSA}$, can serve as alternative energy for RO water purification in the KSA. Using the Jeddah RO3 plants as an ideal plant, consuming $5.06 \mathrm{KWh} / \mathrm{m}^{3}$, the projected MSW-WTE plants coupled to RO systems using the characteristic of Jeddah RO3 will be able to produce fresh water, as seen in Figures 12 and 13.

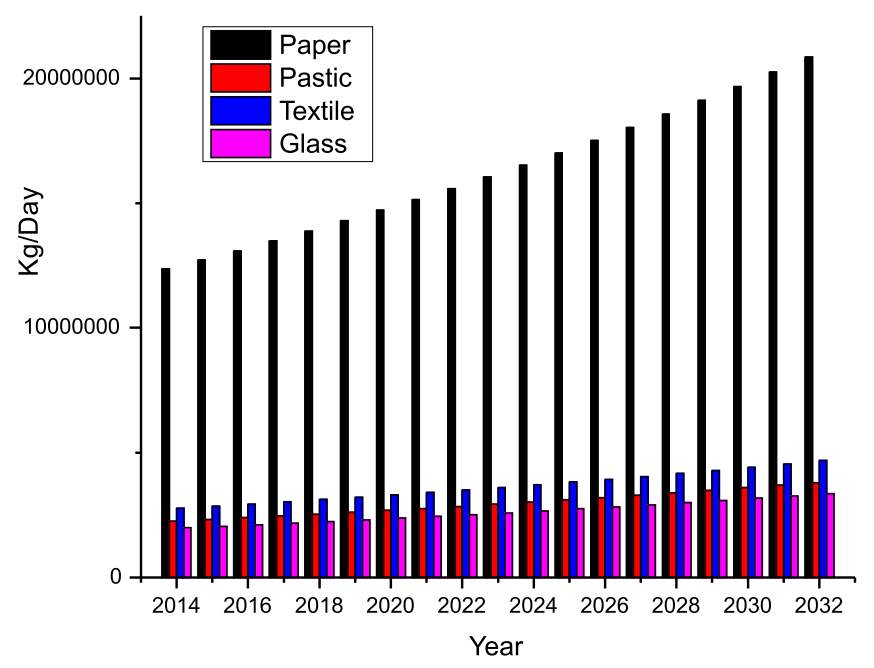

Figure 11. The KSA's MSW Recycling Potentials

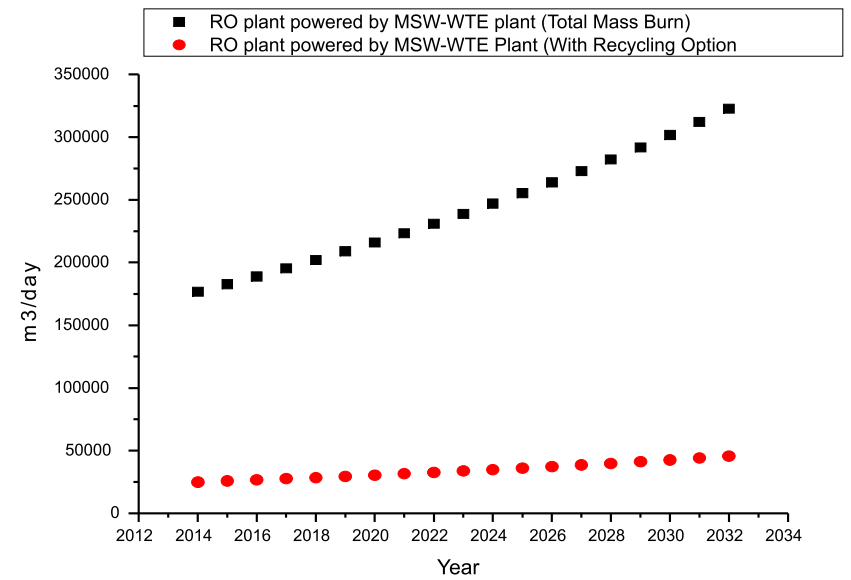

Figure 12. Potential of RO plant powered by the KSA's MSW-WTE 


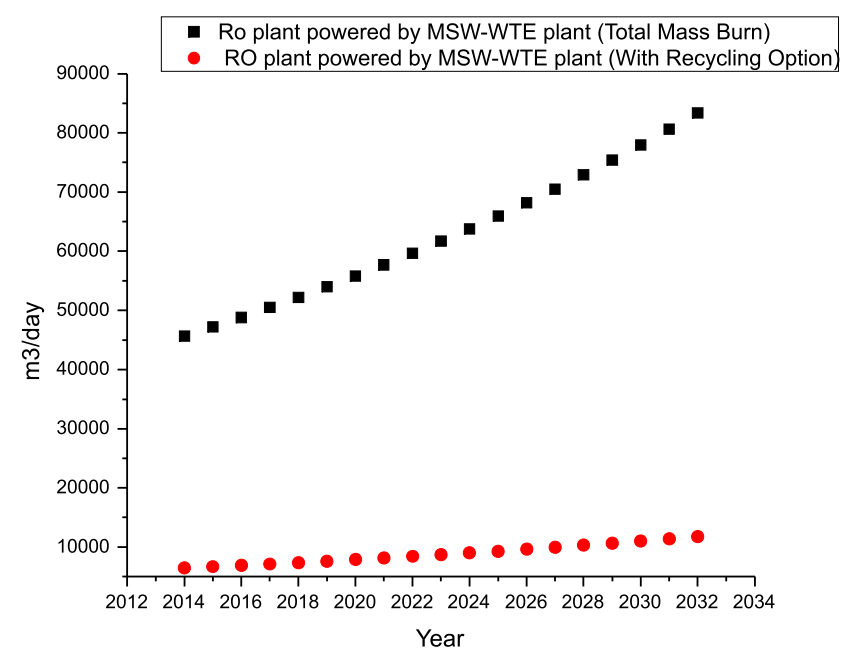

separation of the valuable products of paper, plastic, textiles and glass from the total MSW collected, was estimated at $3225.4 \mathrm{~kJ} / \mathrm{kg}$.

- The total mass burn of all the MSW generated in the KSA will produce $927 \mathrm{MW}$ of electricity of the RO system in 2015 and 1,692 MW in 2032.

- The recycling option of the MSW reduces the energy capacity of the MSW-WTE plants, 131 MW for 2015 and 231MW for 2032.

- The MSW-WTE plants can produce about $1.5 \%$ of the KSA's targeted $120 \mathrm{GW}$ of renewable energy for 2032.

- Using the MSW-WTE to power the RO system, it will provide approximately $16.8 \%$ of the daily fresh water needed for total mass burn and about $2.4 \%$ with the recycling option.

Figure 13. Potential of RO plant powered by Riyadh's MSW-WTE

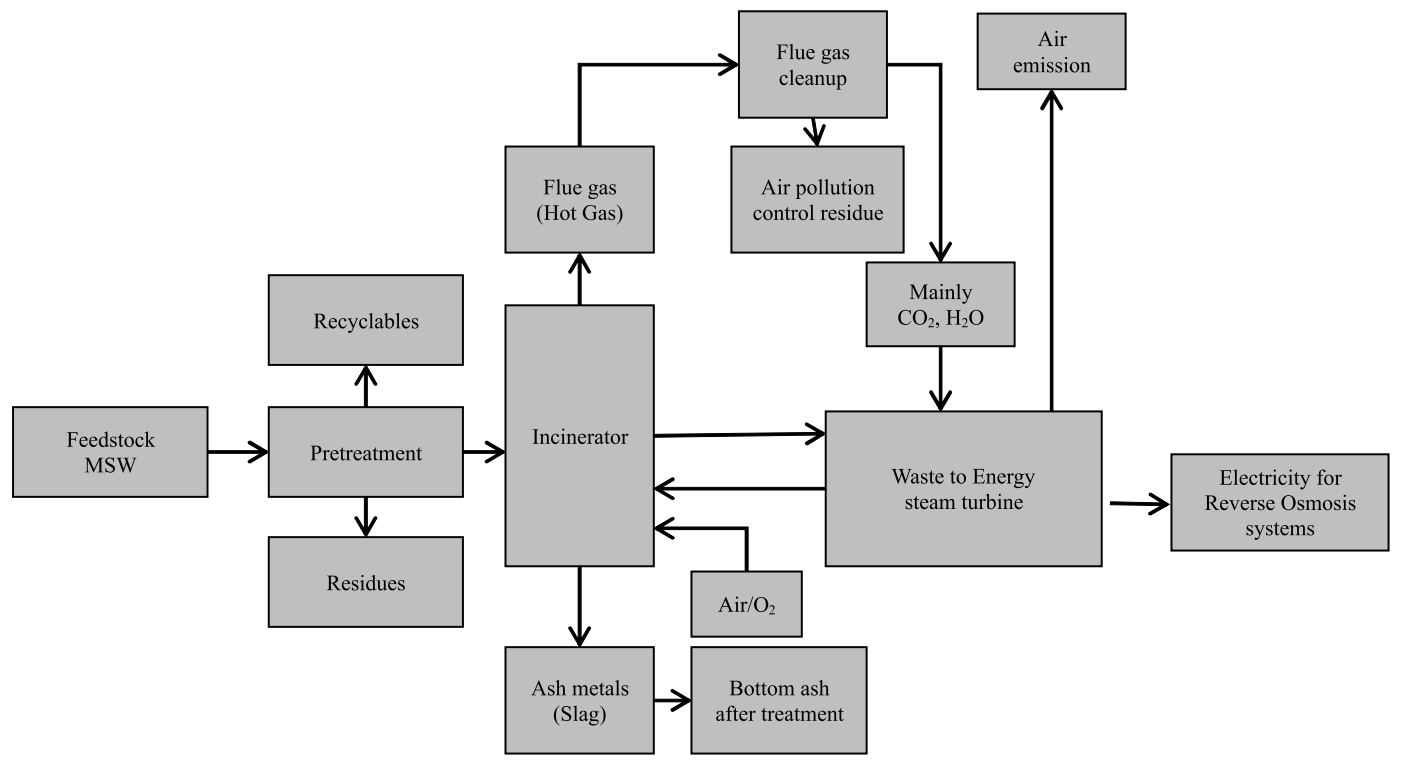

Figure 14. Proposed MSW-WTE RO plant

\section{CONCLUSION}

The feasibility of MSW as an energy source for water purification has been carried out in this work. The investigation revealed some key points for its development into a sustainable energy source for RO plants in the KSA. This work presents some key findings as follows:

- The KSA lacks fresh water resources to meet its daily need.

- Desalination processes like MSF and MED, as employed in the KSA, are energy intensive. Desalination consumes about 1.5 million barrels of KSA Crude Oil.

- The Municipal Solid Waste generation rate per capita in the KSA is between 1.4 to $1.75 \mathrm{~kg} /$ per person/day.

- Water demand forecast based on the three scenarios shows increments, with the optimistic showing a linear trend while the moving average and pessimistic show an exponential increase from 2012 to 2032. In the year 2032 , KSA water demand rose by $52 \%$ by the optimistic scenario. The moving average and pessimistic scenarios forecast increments ranging from $119 \%-221 \%$ of the 2012 demand.

- The energy content of the dry weight of KSA MSW is estimated at $10159.2 \mathrm{~kJ} / \mathrm{kg}$. On the other hand, the mass burn with recycling option, which involves the

\section{ACKNOWLEDGEMENT}

Authors extend their appreciation to Research Center of College of Engineering, Deanship of Scientific Research, King Saud University for funding this work with project No. $4 / 435$.

\section{NOMENCLATURE}

MSW - Municipal solid waste

WTE - Waste to energy

KSA - Kingdom of Saudi Arabia

RO - Reverse Osmosis

MW - Megawatt

GDP - Gross domestic product

BCM - Billion cubic meters

MCM - Million cubic meters

EU - European Union

SWCC - Saline water conversion corporation

MSF - Multi-stage-flash

MED - Multiple effect distillation

KACARE - King Abdullah City for Atomic and Renewable Energy 


\section{LITERATURE CITED}

1. Central Department of Statistics and Information (CDSI). (n.d.). Retrieved May 05, 2015, from http://www.cdsi.gov.sa/ english

2. American Society of Mechanical Engineers. (2008). Waste-to-Energy: A Renewable Energy Source from Municipal Solid Waste. Solid Waste Processing Division and Energy Committee of ASME's Technical Communities of Knowledge and Community. White Paper Submitted to Congress. New York, NY. 3. Dajnak, D. \& Lockwood, F.C. (2000). Use of thermal energy from waste for seawater desalination. Desalination 130(2), 137-146. DOI: 10.1016/S0011-9164(00)00081-3.

4. The World Bank. (2016). World Development Indicators. Washington, D.C.: The World Bank. Retrieved May 02, 2015 , from http://data.worldbank.org/data-catalog/world-development-indicators

5. US Energy Information Administration. (n.d.). Retrieved May 19, 2015, from www.eia.gov

6. KACARE. (2012). Renewable Energy- Waste to Energy, A pillar of the sustainable energy Kingdom. First International Environment Conference, 20-21 November, 2012. King Fahd Civic Centre, Yanbu Al Sinaiyah, Saudi Arabia.

7. Al-Mutairi, S.O. (2009). Production of Compost from Municipal Solid Waste in Riyadh City. Unpublished master dissertation, King Saud University, Riyadh, Saudi Arabia.

8. Ouda, O.K.M. \& Cekirge, H.M. (2014). Potential environmental value of waste-to-energy facility in Riyadh city-Saudi Arabia. Arab. J. Sci. Eng. 39(11), 7525-7533. DOI: 10.1007/ s13369-014-1311-4.

9. Khan, M.S.M. \& Kaneesamkandi, K. (2013). Biodegradable waste to biogas: Renewable energy option for the Kingdom of Saudi Arabia. IJIAS. 4, 101-113. ISSN: 2028-9324.

10. El-Hussein, I., Fayad, W., El Sayed, T. \& Zywietz, D. (2010). A New Source of Power: The Potential for Renewable Energy in the MENA Region. Retrieved May 14, 2015, from Strategy\& http://www.strategyand.pwc.com/global/home/press 11. Eurostat. (2012). Landfill still accounted for nearly $40 \%$ of municipal waste treated in the EU27 in 2010. Retrieved May 17, 2015, from http://ec.europa.eu/malta/news/28.03.12_landfill_en.htm

12. Wang, H. \& Nie, Y. (2001). Municipal Solid Waste Characteristics and Management in China. J. Air. Waste. Manage. 51(2), 250-263. DOI: 10.1080/10473289.2001.10464266.

13. Tang, J. (2012). A Cost-Benefit Analysis of Waste Incineration with Advanced Bottom Ash Separation Technology for a Chinese Municipality - Guanghan. Unpublished master dissertation, Vienna University of Technology.

14. Chowdhury, S. \& Al-Zahrani, M. (2013). Implications of climate change on water resources in Saudi Arabia. Arab. J. Sci. Eng. 38(8), 1959-1971. DOI: 10.1007/s13369-013-0565-6.

15. Ministry of Environment, Water \& Agriculture. (n.d.). Retrieved May 19, 2015, from http://www.mowe.gov.sa/ 16. Saline Water Conversion Corporation. (2015). Annual Report 2014. Riyadh: Kingdom of Saudi Arabia.

17. Ouda, O.K.M. (2014). Water demand versus supply in Saudi Arabia: current and future.

18. challenges. Inter. J. Water Res. Dev. 30(2), 335-344. DOI: 10.1080/07900627.2013.837363.

19. Ministry of Economy and Planning. (2010). The Ninth Development Plan 2010-2014. Riyadh: Saudi Arabia.

20. Gutub, S.A., Soliman, M.F. \& Zaman, uz.A. (2013). Saudi Arabia Confronts with Water Scarcity: An Insight. Inter. J. Water. Res. Arid Environ. 2(4), 218-225. ISSN 2079-7079.

21. World Bank. (2012). Renewable Energy Desalination: An Emerging Solution to Close the Water Gap in the Middle East and North Africa. Washington, DC World Bank. DOI: 10.1596/978-0-8213-9.

22. KACARE. (2013). Towards Sustainable Energy and Mission Driven Research. Sustainable Energy Technologies Centre seminar. 19 April, 2013. King Saud University. Riyadh, Saudi Arabia.

23. US Environmental Protection Agency. (n.d.). Advancing Sustainable Materials Management: Facts and Figures. Retrieved May 22, 2015, from http://www.epa.gov/osw/nonhaz/ municipal/combustion.htm

24. Tan, Y. (2013). Feasibility Study on Solid Waste to Energy Technological Aspects. Fung Technical Report No. 2013.04.15, College of Engineering, University of California, Berkeley, California.

25. World Bank. (1999). Technical Guidance Report: Municipal Solid Waste Incineration. Retrieved May 22, 2015, from http:// www.worldbank.org/urban/solid_wm/erm/CWG\%20folder/ Waste\%20Incineration.pdf

26. Tolba, M.K. \& Saab, N.W. (eds.). (2008). Arab Environment: Future Challenges. Arab Forum for Environment and Development. Retrieved May 22, 2015, from http://www. afedonline.org/en/inner.aspx? contentID $=329$

27. British Petroleum. (2014). BP Energy Outlook 2035: BP Statistical Review of World Energy. Retrieved May 20, 2015, from http://www.bp.com/statisticalreview

28. Hoornweg, D. \& Bhada-Tata, P. (2012). What a Waste: A Global Review of Solid Waste Management. Urban Development Series: Knowledge Papers, no. 15. Washington, DC: World Bank.

29. Ouda, O.K.M., Cekirge, H.M. \& Raza, S.A.R. (2013). An assessment of the potential contribution from waste-to -energy facilities to electricity demand in Saudi Arabia. Energ. Convers. Manage. 75, 402-406. DOI: 10.1016/j.enconman.2013.06.056.

30. Ouda, O.K.M., Raza, S.A., Al-Waked, R., Al-Asad, J.S. \& Nizami, A.S. (2015). Waste-to-energy potential in the Western Province of Saudi Arabia. J. King Saud. Eng. Sci. (In Press), DOI: 10.1016/j.jksues.2015.02.002.

31. Mastro, Lo.F. \& Mistretta, M. (2006). Thermoeconomic analysis of a coupled municipal solid waste thermovalorization-MSF desalination plant: an Italian case study. Desalination 196(1), 293-305. DOI: 10.1016/j.desal.2006.01.014.

32. Ouda, O.K.M., Raza, S.A., Nizami, A.S., Rehan, M., Al-Waked, R. \& Korres, N.E. (2016). Waste to energy potential: a case study of Saudi Arabia. Renew. Sust. Energ. Rev. 61, 328-340. DOI: 10.1016/j.rser.2016.04.005. 